\title{
Corporate Leadership Failure and Its Implications for the consolidation of Corporate Governance and Accountability in Nigeria
}

\author{
Dr. Usman D. Umaru, Adole Raphael Audu, Dr. Mbaya Y. Paul \\ Department of Public Administration Faculty of Management Sciences University of Maiduguri \\ Borno State - Nigeria \\ Department of Public Administration Faculty of Management Sciences University of Maiduguri \\ Borno State - Nigeria \\ Department of Public Administration Faculty of Management Sciences University of Maiduguri \\ Borno State - Nigeria
}

\begin{abstract}
Leadership is at the centre of the successes and failures of corporate organization world-wide. In this paper, leadership is at the centre of corporate failures as exemplified by the failure of some banks and corporations in Nigeria. To avert failure occurrence, this paper recommends that regulatory agencies, Professional Associations/Bodies and Audit firms should be alive to their responsibilities by raising alarm before the harm is done, and where a corporate leader has failed as a result of his/her personal or selfish dealings, an appropriate commensurate punishment should be meted out to him or her, to serve as a deterrent. The analysis of this paper would be through the use of some secondary sources relevant to the theme of this paper.

Keywords: Corporate Governance,Accountabilty,Leadership failure, Nigeria
\end{abstract}

\section{Introduction}

Good corporate governance and proper accountability is the bed-rock of any stable economy in the world. This is unequivocally true in this contemporary world of a complete market economy, based on the dictates of the forces of demand and supply, and the magic of the invisible hands. It is also the believed that a private-sector driven economy is the engine of economic growth and complete emancipation of nations from abject poverty and in some instances, hunger. However, the 2008 world economic financial recession had its roots in United States of America's financial crisis, which emanated from the Wall Street stock crash, as a result of the mortgage industrial collapse of August, 2008. Globalization, which had turned the world in to a global village via the integration of the world economy, ensured that entire world was in one way or the other affected by the recession. For example, the United Kingdom, Japan and Germany were all affected.

In Nigeria, with the withdrawal of $\$ 15$ billion by the portfolio investors from the capital market, the Stock Exchange Market collapsed leading to the loss of Nine (9)trillion Naira; up till now the market has not picked up to the required position. In addition, some public and private organizations were either dead, at the point of death or have become a conduit pipe through which billions of naira and dollars are siphoned. A good example was the Nigeria Tele- Communications Limited (NITEL), Nigerian Railway Cooperation, Nigeria Airways, Power Holding Company of Nigeria, News Watch Magazine, Nigeria Insurance Cooperation of Nigeria (NICON), Ajaokuta Steel Complex, Oceanic Bank Plc, Intercontinental Bank Plc, Afri Bank and Fin Bank. To cushion the effect of the recession, the United States Government under President George Bush provided the sum of $\$ 350$ billion dollars, while president Barrack Obama's government on its part provided the sum of $\$ 780$ billion dollars, respectively, as emergency bail - out to the crisis ridden financial system. Germany on its part, bought- out its second largest bank. In short the world needed about \$4trillion to fully resolve the crisis (Mailiafiya, 2008 [1]). In Nigeria, the sum of N620 billion were injected in to the failed banks by the Central Bank of Nigeria (CBN) in order to revamp them. This recession had brought to the fore the issue of corporate Governance and Accountability particularly as it relates to Public and Private Organizations.

This paper therefore intends to examine Corporate Governance and Accountability in Nigeria by looking at some of the issues from the perspective of leadership failures and of accountability to the stakeholders in particular and the Nigerian nation generally.

\section{Conceptual clarifications}

For easy and proper assimilation of the contents of this paper, it is germane at this point to define the major concepts used in the paper: 
Recession: According to the Advanced Learners Dictionary, recession has been described as a time that is difficult for an economy of a country such that there is less trade and industrial activity than usual with more people out of employment. Depression on the other hand, has been define as a period of little economic activities and many people are poor or without jobs. While recession is a mild but widespread slow down in economy activity, depression is a period during which business and employment remained at low level of activity. The great depression of the $20^{\text {th }}$ century and the great recession of the $21^{\text {st }}$ century that emanated from the Stock Market crash of 1929 and the Wall Street Stock crash of 2008, clearly explained these concepts.

Corporate Governance: Corporate Governance is a process of ensuring that business is run well and investors receive their fair return. It is also a system by which business corporation is directed and controlled (kajola, 2008[2]). But Donovan (2010[3]) define Corporate Governance as an internal system an compassing processes, and people, which serves the needs of shareholders and other stakeholders, by directing and controlling management activities with good business savvy, objectivity, accountability and integrity.

Accountability on the other hand, is a process whereby one who is occupying a position of trust or responsibility is expected to be answerable to the people for action carried out or performance achieved in the discharge of his or her duties, on behalf of the people (UNDP, 1997[4]). Of course, for clarity and absence of doubts in the conduct and account of assigned responsibilities or activities. It is the status of being practically evident, the reality of faithful discharge of duties as required and as accounted for.

Transparency Is personal attribute and it embraces qualities as leadership by example, congruence between words and deeds, trustworthiness, presentation accounts, style, integrity, financial rectitude and generally, being above board (UNDP, 1997[5]).

\section{Efforts on Accountability in Nigeria}

The issue of accountability in government has been with Nigeria for quite some time. In 1978, when former President Olusegun Obasanjo appealed to the conscience of Nigeria, especially, the ruling elites both Military and civilians, to re-orient values and see themselves as trust worthy occupants of their respective offices. To this end, the government then set up the Code of Conduct Bureau and the Public Complaints Commission with the aim of inculcating the spirit of accountability in line with the general expectation of the people. Also General Mohammadu Buhari (Rtd) launched the War against Indiscipline (WAI) with punitive measure for anyone who disobeys the mostly unwritten laws of the campaign. This made Nigeria to embrace the culture of queuing at Bus Stops, Airports, Super Markets, reporting to work punctually and keeping their environment clean. This fear of being penalized or punished spilled in to the conduct of government business, thus, reducing the incidence of fraud and lack of accountability because one never knew who or what one was dealing with, coupled with the long sentences passed on the $2^{\text {nd }}$ Republic office holders. Equally, the late General Sani Abaca's government instituted the War Against Indiscipline and corruption and the failed Bank Tribunal, all in an effort to ensure accountability culture in Nigeria (Abari, 199[6]). Furthermore, in 2003, the civilian Administration of chief Olusegun Obasanjo established the Economic and Financial Crimes Commission (EFCC) and the Independent Corrupt Practices and other Related Offences Commission (ICPC) to check financial crimes and other corrupt practices.

\section{Theoretical perspectives}

Good corporate governance is first and foremost centered on ability of the leadership to influence group towards the attainment of goals by enabling them to contribute towards the effectiveness and success of the organization. The specific behavior of a leader differentiate him / her from other: i.e., effective leadership is the result of effective role behavior attained through the establishment of trust, mutual respect and rapport with the group. But the leadership style exhibited by the leadership of some corporate organizations in Nigeria,

Fall within the Rensis Likert's Four Systems of leadership, specifically the system one theory based on the exploitative authoritative style, in which control is entirely concentrated at the top, such that all decisions are taken at the top and communicated downward for implementation, through the use of threats, reward and punishment to secure performance (Sharma \& Sadana 2010[7]). The resultant effect of these is poor accountability, corruption and collapse of various corporations. These explain the near collapse of some Nigerian Banks and the Nigerian National Petroleum Corporation.

\section{Accountability and leadership failure in Nigeria}

Governance could be analyzed in Nigeria from different environment. For instance, the Political environment has gravely promoted corruption in governance and administration. When a political leader comes to power, he sees his involvement in polities as "bread and butter" as such he venture into profitless adventures 
and wastefulness of public funds thus paving way for deceit, slothfulness, indiscipline and poverty (Habib, 1999 [8])

Again, political factors also have had various effects on good governance both in the Nigerian public service. And the organized private sector that is why Afigbo and Uya (2000[9]) observe that: thus at independence in 1960, the main features of the Nigerian state that had evolved since 1900 were: weak constitutional and institutional basis for the development of politics; an unbalanced federation; regionalism which engendered mutual jealousy and fear; and regionally based political constituencies. This was the political environment as at independence. This situation could not permit the administrative ethics and practices passed on by the British authorities to become stable and institutionalized. This point of view was supported by Sklar (1967:54[10]) when he said that: after independence, Nigerian politicians and administrators themselves lacked the political experience and skill to run the parliamentary system of government borrowed from the British. They made grave errors of omission and commission which were compounded by political intolerance; inter ethnic antagonism, corruption, political repression and injustice. This was the scenario that characterized the first republic. The country was enmeshed in instability and therefore, the growth and maturity of the administrative structures, ethics and practices was grossly stifled. The civil bureaucracy put in place became an object of scorn.

The scenario encapsulated above is true of politics in Nigeria and therefore has affected administration in the public service in many dimensions including the following:

Emphasis is now laid on politics rather than good governance and accountability. The sovereignty of politics is emphasized rather than the impartiality of administration. Usually, political values are emphasized and they tend to take precedence as well as dominate administrative values of anonymity, impartiality and neutrality. In the end, you have the practice of public administration that is highly politicized despite the inherited structure and values of administration that are expected to be based on a high degree of professionalism. But the ascendancy of political values over those of public administration is mainly for exploiting and using power for personal gains (Sorkaa, 2003[11]).

Another dimension of the political factor is that the existing political environment has also promoted corruption in governance and administration. When a political leader comes to power, he faces two main problems. Firstly, there is usually a lack of a national political culture that especially promotes an institutionalized political system that guarantees safe entry into power and safe exit. What this means is that you cannot guarantee the political leader safety or survival on the seat of power. Hence, the tendency to bend the rules of fair play and administrative values to perpetuate himself in power, secondly, political leaders on coming to power face the problem of getting political power without economic power. Hence, political power is looked upon in Africa as the avenue for building financial empires.

Socio-cultural dimensions constitute another ecological factor that affects ethics, accountability and practices in administration. There is a cultural dimension to the issue of ethics and accountability in the public service of African states, including Nigeria. Nigerian cultures generally value communalism rather than individualism or privatization, which is typical of western culture. In fact, privatization of interests is meaningless and useless. To Africans in general and Nigeria in particular, communalism is a progressive mechanism which has encouraged the collective accumulation of wealth. It is, in fact, a strong element of social or mechanical solidarity. The effect of this on ethical concerns in administration is that, the extended family connections usually overstretch the salary of a public servant and, therefore, makes him look for extra income through unethical ways.

Again, ethnic or tribal affiliations and friends also affect the behaviour of public servants. Certain employment opportunities are granted to in-laws, other family relations who may not necessarily be qualified. This is a breach of civil service rules.

In his own attempt to describe the extent of society and government insensibility to effective Administration (Onochic, 2001[12]) stated that:

The general low wages, unemployment and poverty are factors which impel men tolerate corruption and lack of accountability ...... the same applies to government authorities who refuse to sanction other public officers due to lack of probity... those who insist on accountability have gotten their hands burnt.... In most cases those who flout the provisions on accountability and probity are the ones that get promoted or rewarded.

The Nigerian nation, with all its resources belong to all Nigerians, people in leadership position must understand that they hold the resources in trust for the entire citizenry as well as posterity. They should therefore ensure that national resources are transparently expended and publicly accounted for in such a way as will bring increasing level of benefit to the majority of Nigerians. For in this lies the possibility of building protection for our people and in return the extension of loyalty from the ethnic groups to the nation. According to the United States National Intelligence Council (2005: 15[13]) "corruption thrives in Africa partly because the processes of the exercise of power in decision making are not sufficiently open and subject to accountability 
and transparency. These processes also allow for too much arbitrariness .... If those who make and implement policy in public, private and religious endeavours cannot be held accountable, their offices are prone to abuse. The Nigerian economy has been variously described as capitalist, mixed, under-developed among others. The advent of capitalism has increases the quest for accumulation of wealth by public office holders. Public office holders now see themselves as "fortunate" people because their positions have afforded them the opportunity to en mass wealth. Salem (2003 [14]) advanced that the above scenarios have a number of effects on slow human development:

a. Corruption raised transaction costs and uncertainty in the economy.

b. It skews the policy-making process and results in inefficient and irrational out comes.

c. It is regressive in that it lays a large burden on small and medium enterprises that need to set aside a large share of their time and income to deal with it.

d. It undermines state legitimacy and the rule of law.

e. It leads to wider income disparities because those with influence gain more advantages; and those without lose out.

Again, decline in the official earnings of civil servants is another economic factor that has impinged on administrative development in the country. In the Nigerian public service, it is known that a major motivation to employee's performance is the level of compensation for services rendered. A poorly compensated staff cannot be expected to contribute his best whether in the public or private sector of the economy (Sorkaa, 2003[15])

As a consequence, workers have evolved other means of supplementing their incomes. This is done in order to meet their basic needs as well as sustained needs of self-esteem and status. So, it has now become the accepted practice for people to use the public service and their official positions to compensate themselves. Hence, illegal, unethical opportunities for extra income dominate the workings of the public service in Nigeria. Again, Sorkaa (2003[16]) explained that presently emphasis is now placed on politics rather than administration. The sovereignty of politics is emphasized rather than the impartiality of administration usually, political values are emphasized and they tend to take precedence as well as dominate administrative values of anonymity, impartiality and neutrality. In the end, you have the practice of public administration that is highly politicized despite the inherited structures and values of administration that are expected to be based on a high degree of professionalism. But the ascendancy of political values over those of public administration is mainly for exploiting and using power for personal gains. The body (Transparency International) in their corruption perception index in early 2004, pronounced Nigeria as one of the most corrupt nations in the world. This was in spite of the fact that democratic institutions had been introduced and the anti-corruption commission set up. As at today (2013), Nigeria occupies the last but one position down the ladder among nations adjudged to be corrupt by Transparency International Corruption perception index because of its blatant disregard for good governance practices and administration.

It is against this backdrop that the federal government of Nigeria particularly the government of former president Olusegun Obasanjo established the Economic and Financial Crimes Commission (EFCC). The EFCC is a Nigerian law enforcement agency that investigates financial crimes such as advance fee fraud (419) and money laundering. The EFCC was established in 2003, partially in response to the pressure from the Action Task Force on money laundry (ATF) which also named Nigeria as one of 23 countries non-cooperative in the international community effort to fight money laundry. Again, the resolve to fight and win the war against corruption in Nigeria led to the promulgation of the Corrupt Practices and other Related offences Act 2000. According to Raji (2007[17]) "The Act was the first bill presented by former president Olusegum Obasanjo to the national Assembly for consideration at the inception of democratic administration in 1999". The act establishes the Independent Corrupt Practices and other Related offences Commission, which is the apex body saddled with the responsibility of fighting corruption and other related offences.

Section 6 of the Act that established the ICPC, confers three main responsibilities on the commission, they are:

1. To receive and investigate reports of corruption and in appropriate cases prosecute the offender(s).

2. To examine, review and enforce corruption prone systems and prosecution of public bodies, with a view to eliminating corruption in public life.

3. Educating and enlightening the public on and against corruption related offences with a view to enlisting and fostering public support for the fight against corruption.

Despite the good intention of late President Umaru Musa Yar'Adua to fight corruption in the Nigerian public service the problems of graft, bribery, corruption and unprofessional behaviour of public servants continue to persist. From the foregoing analysis, it can be clearly seen that some of the Accountability Institutions like: The Independent Corrupt Practices and other Related offences Commission (ICPC), the Economic and Financial Crimes Commission (EFCC), the Public Complaint Commission, The Code of Conduct Bureau and a host of other relevant accountability institutions in Nigeria are confronted with a lot of challenges. 


\section{The nature of Corporate governance and Accountability in Nigeria}

The structure of corporate governance is centered on the boards, managers, and the shareholders. It is this structure that determines its successes and failures. As such, the relationship of the board and management should be characterized by transparency to shareholders and fairness to the stakeholders. Therefore, good corporate performance relates to the way and manner in which financial resources available to an organization are judiciously used to achieve the overall corporate objective, thus keeping the organization in business and creating good prospect for future opportunities (Kajola, 2008[18]).

In Nigeria, most public and private corporations were either dead, became a conduit pipe through which billion of naira are siphoned or are at the point of death. A good example are the Nigerian TeleCommunications Limited(NITEL), Nigeria Railway Corporation, Power Holding Company of Nigeria, Ajmaokuta Steel Complex, Nigeria Air ways, Albarka Air, Transcorp and the likes. While some banks that were at the point of collapse or bankruptcy were saved by the Central Bank of Nigeria: Oceanic bank, Intercontinental Bank Plc of Nigeria, Afro Bank Plc of Nigeria, Union Bank Plc and Fin bank Plc.These were made worst by the financial economic recession of 2008 that affected the Nigeria Stock Exchange market. The near collapse of the Nigeria Stock Exchange at the early stages of the recession exposed the recklessness, appalling abuse of loans in the Nigerian banking sector. According to Oyebode, (2009[19]) the massive fraud and cooking of books in companies, such as Cadbury Nigeria limited, together with the insider dealings and compromised boards in many companies together with the spineless shareholders association and audit committees, coupled with rubber stamped Annual General meetings being held, suggested the total collapse of corporate Governance in Nigeria. He further pointed out that corporate failure is not peculiar to Nigeria alone, because even in the United States of America, big corporations such as Northern Rock, HBOS, Freddie Mac, Fanny Mae, Lehmen Brother, Bear sterns, AIG investment banks etc have all failed.

In the United States of America, the Executives of these corporations were accused of recklessness and insensitive to the plight of their various shareholders. In Nigeria, it was a common knowledge of what happened to the chief Executives of these banks: they were all sacked by the central Bank of Nigeria._As earlier mentioned, leadership is the determinant of the success or failure of any corporate organization. This assertion had come to play in the scandals that rocked some Nigeria banks, as earlier mentioned above. As we all know, Banking is a profession where trust, credibility, dependability, reliability and efficiency are highly cherished. Once banks losses most of these traits, then its standing is eroded (Nmodu, 2009[20]).The Chief Executives of these failed banks in Nigeria were not worthy of the confidence reposed in them, because of the way and manner they handled depositors funds in their respective banks._For example, the former managing director of Oceanic Bank was alleged to have granted reckless credit facilities to the tune of more than N16 billion naira; the Managing Director of Intercontinental Bank and his cronies. Also, the Managing Director of Fin bank could not account for about N37.84billion. While the managing Director of Afri bank gave out loans without collateral to the tune of more than N150 billion. To save the whole bank from bankruptcy, the Central Bank of Nigeria had first sack all these managing Directors and then injected about N620 billion naira into the sector.

Another case of lack of accountability was the allegation of fraud perpetuated by some past Managing Directors of the Nigerian National Petroleum Corporation. Apart from that, some of them were involved in the Halliburton and Wibros bribery scandals. For example, one of them was caught red -handed with $\$ 2$ million cash which he was unable to account for; another was said to have appropriated the sum of $\$ 17$ million meant for the Turn Around Maintenance of the Kaduna Refinery. In addition, the Managing Directors were said to have formed the habit of not remitting proceeds realized from the sale of Nigeria crude oil to the federation account. (Ibrahim, 2010[21]).

It is pertinent to state here that the Central Bank of Nigeria, the Security and Exchange Commission of Nigeria, Corporate Affairs Commission of Nigeria, the Independent Corrupt Practices and other Related Matters Commission, the Economic and Financial Crimes Commission, the Institute of Chartered Accountants of Nigeria, Association of Nigerian Accountants etc were all at one time or the other impotent to the happenings within the various corporate agencies in Nigeria. In the case of the failed Nigerian banks, the Central Bank of Nigeria, the Security and Exchange Commission and some external auditors who are members of either ICAN or ANAN and other related professional bodies, should have exposed these distressed banks earlier on, but they rather choose not to expose them.

\section{Conclusion}

The need for organizations to make explicit the behaviour expected of leaders in an organization is widely recognized. For example Ingrid and Fishers (2005[22]) advice organizations to "clarify the standards of ethical behaviour required of key executives.... and encourage the promotion of those standards. In similar manner, the Australian stock exchange (ASX2003 [23]) recommended establishing a code of conduct that identifies good practices for executives both in the public and organized private sector. The ASX suggests that other key executives should preserve the ethical reputation and integrity of the organization and outlines the 
responsibilities of individuals to report unethical practices. ASX also suggests a number of areas with which code of conduct should deal: Conflicts of interest, corporate opportunities, confidentiality, fair dealing, and protection of the organization's assets, compliance with laws and regulations and encouraging the reporting of unlawful/unethical behaviour. together with their respective professional bodies or associations, based on negative "spirit de corp". The consequences of these were that Nigerians have lost faith in the buying of shares; keeping money in the banks and above all trusting Chief Executives of Corporations in the country.

\section{Recommendations}

Regulatory agencies and professional bodies should be alive to their responsibilities by raising alarm before it is to late whenever fraud or shoddy deals are discovered in any cooperate organization, no matter who is involved; professional Associations or bodies should desist from shielding their members who abuse the trust reposed on them. This will make the professional bodies or agencies gain the trust and respect of members of the public; Books of corporate organizations should be subjected to surprise checking by regulatory agencies or audit firms to prevent abuse and fraud; Chief Executives of Corporate Organizations found to have lived above his or her earning should be made to account for the excesses and such assets or funds be forfeited to the government. Finally, life imprisonment should be the punishment for corporate Chief Executives who abused their positions.

\section{References}

[1] M. Mailafiya,. (2009). Lagos, Newwatch Magazine, June $18^{\text {th }}$

[2] S.O Kajola, S.O Corporate Governance and Firm Performance. The Case of Nigerian Listed Firms. Accessed at $\mathrm{http} / /$ www.eurojournals.com.2008

[3] L.Donovan, Corporate Governance. Can be accessed at http//e.wikipedia.org/wiki/Corporate governance.2010

[4] UNDP Training Manual, NCENA, January, 1997, Nigeria.

[5] UNDP Training Manual, NCENA, January, 1997, Nigeria.

[6] G .Abari, Manifestation of poor financial Accountability in the Civil Service, in Accountability in Government: the Role of the Civil Service. Nigerian Civil Service Union, Borno State. 1996

[7] Z.M Habib, Democracy and the Story of a Struggle in Nigeria. Northern Star,, Kaduna, 1998

[8] A.Afigbo, and O.E Uya, O.E “The Evolution of Nigeria 1949-1960" in: B.J Adaegbu, and D.Mathew [Eds]. A People United, Future Assured Spectrum Books Ltd, Ibadan.2000

[9] P.A Sorkaa Development as Ethics and Accountability in Governance: The way forward for Nigeria. The BSU Press 2003

[10] United States National Intelligence Council "Why Nigeria May Become a Failed State" Retrieved from www.vanguard ng.com.articles/June 05/0336205/phtml 2005

[11] P . Salem, P The Impact of Corruption on Human Development in the Arab World. Lebanese Transparency Association, the Fares foundation. 2004

[12] P.A Sorkaa Development as Ethics and Accountability in Governance: The way forward for Nigeria. The BSU Press 2003

[13] P.A] Sorkaa P.A [2003] Development as Ethics and Accountability in Governance: The way forward for Nigeria. The BSU Press 2003

[14] H. Raji, "Nigeria Independent Corrupt Practices and other Related Offences Commission. A Brief Overview" Retrieved from http/www.ca/org.uk/issues/17 eng/button 2.html 2007

[15] S.O Kajola,. Corporate Governance and Firm Performance. The Case of Nigerian Listed Firms .Accessed at http//www.eurojournals.com.2008

[16] A .Oyebode, A. (2009): The Imperative of Corporate Governance in Nigeria. Accessed at the Internet

[17] D Nmodu, (2009): Sanusi Unusual Rebellion. Lagos, Insider Weekly, Magazine, September $9^{\text {th }}$.

[18] I Ibrahim, the Plundering of N.N.P.C. Lagos, Newswatch Magazine, April, $19^{\text {th }} .2010$

[19] B .Ingrid, and I .Fisher, "Corporate Governance and Business Ethics: Insights from the Strategic Planning Experience". Journal of Corporate Governance 13.(6) Oxford, USA

[20] Australian Stock Exchange "Principles of Good Corporate Governance and Best Practice Recommendations" Journal of Australia Stock Exchange. 16( 8) PP 23-26. 2005 